\title{
IMPROVING COLLABORATION IN BLENDED LEARNING ENVIRONMENTS THROUGH DIFFERENTIATED ACTIVITIES AND MOBILE-ASSISTED LANGUAGE LEARNING TOOLS
}

\author{
Ajda Osifo \\ Zayed University, UAE
}

\begin{abstract}
Recent trends in higher education have initiated an increase in the attention given to the quality of teaching offered to the students, and significant changes in student populations since 2000, such as increasing social diversity (Biggs \& Tang, 2011), have required educators to relook at their teaching and instructional practices. As diversity in higher education increases and accelerating technology adoption impacts on teaching, improving the quality of the instructive-educational process becomes fundamental based on understanding, observing, and re-evaluating the differences amongst our students. At the higher education level, our students are even more diverse than K-12 students due to their academic experiences and professional interests. Our learners differ not only culturally or linguistically, but also in their cognitive abilities, learning preferences, background knowledge, and have various levels of strengths and weaknesses in the area of multiple intelligences; hence a rethinking of the structure and management of the classroom, modifying curricula and maximizing classroom interactions are necessary. Differentiated activities together with Web 2.0 tools and mobile-assisted language learning applications can enhance collaborative learning where learners actively participate in groups to explore a topic or discuss to finalize a project. Differentiation or academically responsive instruction concentrates on teaching strategies that provide students with multiple pathways in the teaching and learning process to meet their needs. Mobile-assisted language learning (MALL) is a subarea of mobile learning in which integration of new mobile technologies into teaching and language learning has been a primary focus, and numerous mobile applications and online Web 2.0 tools have been developed to support academic English language learning, including reading, listening, writing, speaking, functional grammar and vocabulary. Web 2.0 refers to a huge array of web-based tools such as blogs, wikis, folksonomies, social networking sites and content-sharing sites which can offer numerous instructional opportunities like active engagement, personalized learning and innovation, and can empower and enable learners to participate in a variety of ways. This qualitative study explored the integration of MALL applications and Web 2.0 tools in differentiated EAP classes and sought to understand how they can assist in improving collaboration of EAP students to achieve higher levels of cognitive learning in higher education in UAE. The findings suggest that the usage of MALL apps and Web 2.0 tools in differentiated EAP classes in higher education assist students in terms of feedback, motivation, collaboration, pace, multi-modality and research skills; gives them an opportunity to choose the activity and the type of assessment that corresponds to their needs and abilities.
\end{abstract}

\section{KEYWORDS}

Collaboration, Mobile Language Learning, Differentiation

\section{INTRODUCTION}

Preparing students for the future is the core mission of higher education institutions (NMC Horizon Report, 2017). Over the past two decades, higher education in many countries has expanded as the number of students has increased significantly, access to education has improved and the student body has diversified (Henard $\&$ Leprince-Ringuet, 2008). As higher education continues to move away from traditional lessons toward more multifaceted interactions, educators are also expected to employ technology-based tools and mobile learning pedagogies. In blended learning environments, where a combination of delivery methods including face-to-face instruction and asynchronous/asynchronous technologies are used, higher education is well 
positioned to implement mobile technology into the classroom to address various learning styles of different students and to provide personalized learning experiences (West, 2013).

Differentiated instruction together with MALL and Web 2.0 tools have the potential to reach more diverse students in academic English language classes in higher education. The current qualitative research study in the form of action research, explored the integration of MALL applications and Web 2.0 tools in differentiated EAP classes and how they can assist in improving collaboration of EAP students in higher education in UAE. As there is a significant need to develop evidence for utilizing MALL apps and Web 2.0 technologies in classes to serve a diverse student population, action research methodology in this study offers a critical examination of a teacher's self-practices. One application of this study is to better meet the needs of diverse students in our classrooms by investigating the effect of integrating new technologies in our instructional design, which will lead to changed practices. In addition, as further research needs to be conducted at the higher education level to better understand differentiated instruction (Tulbure, 2011; Koutselini, 2008), this study, although limited, provides insights on utilizing it in EAP tertiary classes, thereby promoting the differentiated instruction approach.

\section{BODY OF PAPER}

In the United Arab Emirates (UAE), public and private universities are becoming more engaged with the new educational technologies as they attempt to get international accreditation. There have been governmental efforts to create structures for complete programs to include new mobile-enhanced delivery models that target specific student populations and can increase access to education. The landscape of higher education in United Arab Emirates (UAE) today includes the incorporation of Web 2.0 technologies and MALL tools into learning and teaching processes for more effective practices and strategies to redefine the task of learning. Although both governmental and higher education efforts have resulted in large-scale initiatives to integrate educational technologies in relevant curricula, firstly, students in the classrooms are diverse. Thus, the specific needs of the targeted student populations have to be accommodated. At present, there is a shortage in studies addressing diversity of students and their academic English language education, especially in a relatively more conservative Middle East region. Secondly, students entering foundational academic English language programs in the UAE universities are unfamiliar with active learning and frequently have problems adapting to the new setting (Rugh, 2002). They often lack the skills needed to learn actively such as critical thinking and problem solving skills, research skills, creativity and independent learning skills which may leave them unmotivated and discouraged. Consequently, there is a strong need for an effective teaching approach that educators can utilize to reach all students in their classrooms, and also evaluate academic readiness, learning progress and other educational needs of students.

According to Prud'homme et al. (2006), the term "differentiation" is labelled in various ways when a corpus analysis is done, such as "differentiated classroom", "differentiated instructional design", "adaptive education", "adaptive teaching", "mixed-ability grouping", "individual differences", "diversity in education", "cultural diversity" and "aptitude". They further state that the concept of differentiation is complex as theorists do not always agree on its nature. For example, it may mean to be "a tool, an attitude or a teacher's impact, an approach, a system of beliefs or a philosophy, a strategy for curriculum adaptation, an organizational strategy, a process for change in practices or a model for class management" (p.135). For the purposes of this research study, differentiation is seen as defined by Stradling and Saunders (1993): "the process of matching learning targets, tasks, activities, resources and learning support to individual learners' needs, styles and rates of learning" (p.129). It involves flexible learning activities experienced within meaningful situations adapted to the students' level, as opposed to traditional, rigid methods.

Although there are plurality of theoretical perspectives on differentiated instruction, it is commonly perceived as part of the socio-constructivist paradigm of learning which emphasizes the active participation of students in the learning process where construction of knowledge emerges due to the interactions of students with one another, their teachers, physical space and arrangement, and educational materials (Tomlinson, 1999; Subban, 2006). This study is grounded in the socially constructed ontology and rests on an epistemology that recognizes multiple realities. Knowledge is actively constructed within social interactions. Figure 1 shows an overview of the theoretical framework for this study. 


\section{Theoretical framework:}

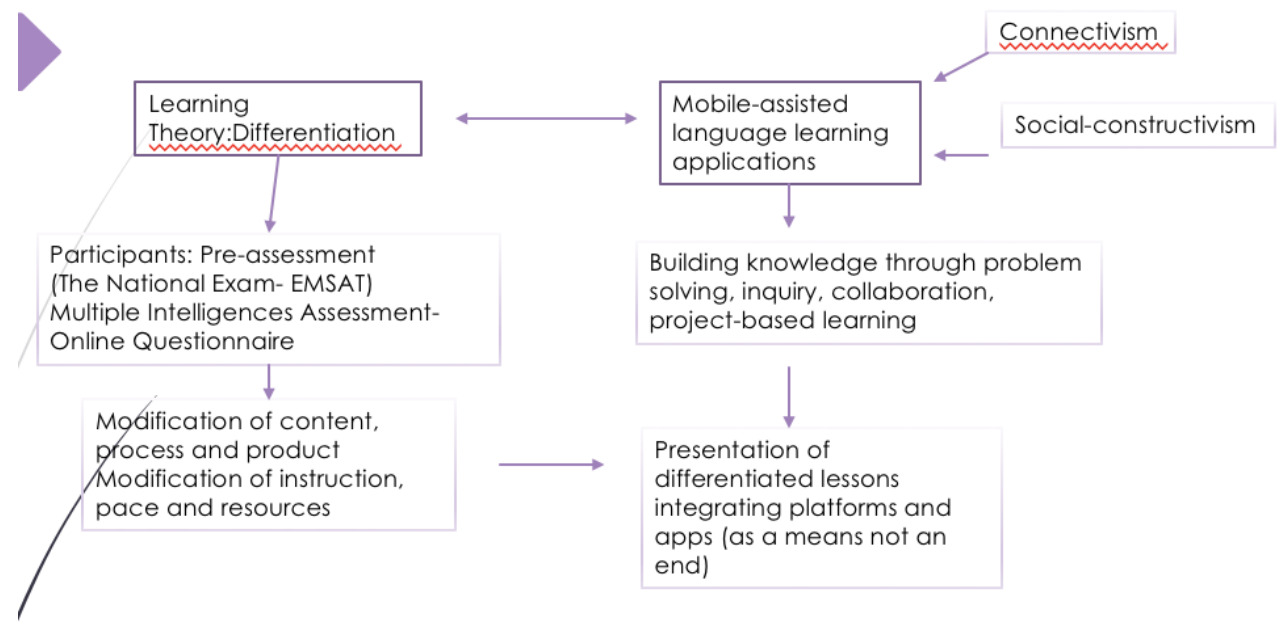

Figure 1. Overview of the Theoretical Framework

This study was conducted at a federal government university, where English is the medium of education, and classes are segregated. In the UAE, women are currently being encouraged to pursue higher education and then enter the workforce. Abdulla and Ridge (2011) observed that in 2011, 70\% of students in higher education were female which illustrates that more females than men have taken up the opportunity of free education in UAE. The participants were 30 female Emirati students in the foundation program, all of whom spoke Arabic as a first language, and who did not meet the language entrance requirement for baccalaureate study and entered the academic English course. The female Emirati students in classes are diverse in terms of their cultural background, communities they belong to, educational background, and resilience and adaptability.

\subsection{Data Collection Methods}

The key question guiding this research study is "How can MALL applications and Web 2.0 tools assist EAP students in differentiated lessons in UAE higher education?". To answer this question, the action research design facilitated the gathering of qualitative data through an online multiple intelligences questionnaire, a paper-based questionnaire and semi-structured student interviews. Firstly, an online multiple intelligences questionnaire which was designed by Armstrong (2009) was conducted as part of a class activity, and was used to determine students' intelligence strengths and preferences. This information was important for arranging students into appropriate groups for differentiated lessons. Students were observed by the teacher for a period of 9 weeks and by the time the differentiated lessons were presented, the teacher could cater the differentiated lessons to the interests of the students to improve collaboration and provided them with options at varying levels of difficulty. These lessons included differentiated activities in four skill areas which are listening, speaking, reading and writing, and are scaffolded, including problem-solving tasks where students had to find information through research and shared it with their peers in order to build up an understanding of a real-world problem, and projects where students were encouraged to become content generators and reflect on their own learning. After the completion of both differentiated lessons, participants were given a paper-based questionnaire with ten questions which included closed and open-ended questions. Questions included MALL apps and Web 2.0 tools which were used during the presentation of differentiated lessons, such as Keynote, Padlet, Hemingway writing app and QR codes. Figure 2 shows examples of differentiated activities that were a part of the two separate differentiated lessons. All activities that took place incorporated various MALL apps and Web 2.0 tools as part of the intervention. 


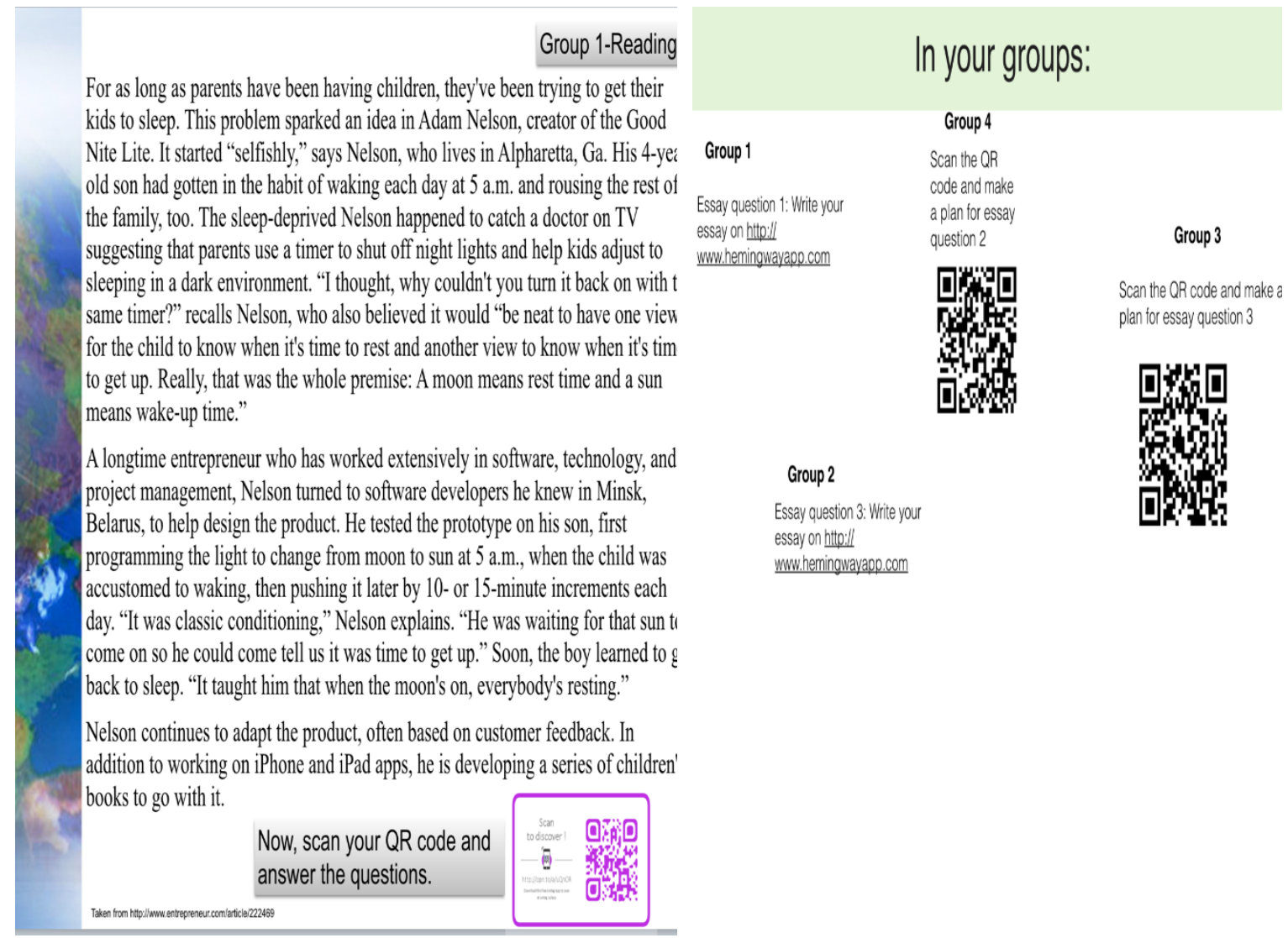

Figure 2. Examples of Differentiated Activities

\subsection{Data Analysis and Results}

As flexible grouping is essential in differentiated lessons, the online multiple intelligences questionnaire was used as pre-assessment data to group students in classes, however, students moved in and out of groups depending on the activities. As Gregory \& Kuzmich (2004) suggest students were grouped according to their interests, their multiple intelligences, thinking skills and abilities for class activities.

The data analyzed from the paper-based questionnaire is used to reflect on the educational practice of the researcher and shape the following iterations in the next cycle. Table 1 provides the common themes in open-ended responses in the paper-based questionnaire: 
Table 1. Common themes in open-ended responses in the paper-based questionnaire

\begin{tabular}{|l|l|l|c|}
\hline $\begin{array}{l}\text { Question } \\
\text { No }\end{array}$ & $\begin{array}{l}\text { Common Themes in Open-ended } \\
\text { Responses }\end{array}$ & $\begin{array}{l}\text { No of Responses } \\
\text { Applied to the Theme }\end{array}$ & Examples of Participant Responses \\
\hline
\end{tabular}

\begin{tabular}{|c|c|c|c|}
\hline 4 & $\begin{array}{l}\text { - a) learning from each } \\
\text { other } \\
\text { - b) better motivation }\end{array}$ & 10 & $\begin{array}{l}\text { a) I try to check the meaning of new words } \\
\text { and communicate with others using it. } \\
\text { b) I like when I have a Keynote because I } \\
\text { like doing many different activities and } \\
\text { learning new words. }\end{array}$ \\
\hline 5 & - $\quad$ pace & 5 & $\begin{array}{l}\text { It gives me time to read in my group. For } \\
\text { example, it helps me to read the text and have } \\
\text { a plan before we start. }\end{array}$ \\
\hline 6 & $\begin{array}{l}\text { - } \\
\text { - } \quad \text { b) motivation } \\
\text { texts }\end{array}$ & 6 & $\begin{array}{l}\text { a) I want to do it again and it was fun. } \\
\text { a) It's good because all groups have a } \\
\text { responsibility to plan and present. } \\
\text { a) I like it but not too often. } \\
\text { b) Taking a photo and seeing a website or } \\
\text { a picture helps me. } \\
\text { b) It will help us to find different activities } \\
\text { and if we have same activities for all groups it } \\
\text { is boring. }\end{array}$ \\
\hline 7 & $\begin{array}{ll} & \text { a) fun } \\
\text { - } & \text { b) collaboration }\end{array}$ & $\begin{array}{l}8 \\
4\end{array}$ & $\begin{array}{l}\text { a) It will help me to have many ideas from } \\
\text { others and it's easy and exciting. } \\
\text { b) I like to use it again to put a box for } \\
\text { problems and solutions after talking to my } \\
\text { group. } \\
\text { b) Yes, sure because we should share our } \\
\text { ideas and this will help us in our exams. }\end{array}$ \\
\hline 8 & $\begin{array}{l}\text { - } \\
\text { - } \quad \text { b) improving } \\
\text { organization skills }\end{array}$ & 3 & $\begin{array}{l}\text { a) I believe apps are an easy way to search } \\
\text { and it already have the activities. } \\
\text { a) Using an app and dividing class into } \\
\text { groups is easy to get information. } \\
\text { b) I use Keynote for everything, because its } \\
\text { help me to organize and plan and do well. }\end{array}$ \\
\hline 9 & $\begin{array}{l}\text { - } \quad \text { a) providing feedback } \\
\text { - } \quad \text { b) personalization }\end{array}$ & 6 & $\begin{array}{l}\text { a) It is the best; it makes me focus and look } \\
\text { where my mistakes are. } \\
\text { b) It really help me to know my mistake, } \\
\text { like if there are colors I know I have a mistake } \\
\text { in the sentence. } \\
\text { b) I can write my ideas and others can write } \\
\text { their ideas at the same time, so we can all see } \\
\text { everything. It's fun and sometimes difficult. }\end{array}$ \\
\hline 10 & - $\quad$ preferences & 17 & $\begin{array}{l}\text { It is better to read a book and answer the } \\
\text { question in notebook. } \\
\text { Traditional study methods are boring. } \\
\text { I will feel confused when I need to find } \\
\text { information. }\end{array}$ \\
\hline
\end{tabular}


Table 2 outlines the themes, number of references and corresponding data samples of the interviews:

Table 2. Themes, number of references and corresponding data samples of the interviews

\begin{tabular}{|c|c|c|}
\hline Theme & $\begin{array}{l}\text { Number of } \\
\text { references }\end{array}$ & Sample Corresponding Data \\
\hline $\begin{array}{l}\text { MALL apps and Web } 2.0 \\
\text { tools giving feedback }\end{array}$ & 8 & $\begin{array}{l}\quad[\ldots] \text { They give us "it's wrong word". } \\
{[\ldots] \text { It tells us what's wrong.. where the wrong word or the wrong }} \\
\text { space is. } \\
\text { Hemingway app is good for us for writing, because we learn our mistakes } \\
\text { for writing. And we see what we need in a paragraph. It helped us organize } \\
\text { our essay and also brainstorm ideas. } \\
\text { Hemingway writing app makes me crazy. I see all the different colors and I } \\
\text { get frustrated with my mistakes. }\end{array}$ \\
\hline $\begin{array}{l}\text { Student learning } \\
\text { preferences }\end{array}$ & 6 & $\begin{array}{l}{[\ldots] \text { especially keynote because it has a lot of information and we do it in }} \\
\text { groups. } \\
\text { I save the keynotes and when I review work, and if I missed some vocab, I } \\
\text { just review keynotes. That helps me. }\end{array}$ \\
\hline $\begin{array}{l}\text { MALL apps and Web } 2.0 \\
\text { tools supporting } \\
\text { conversation and } \\
\text { collaboration }\end{array}$ & 5 & $\begin{array}{l}{[\ldots] \text { actually I like that, because we.. chatting.. we.. as group you know.. I }} \\
\text { think that's help me to write about things and search about the information... } \\
\text { I like different groups and different activities, because I think we didn't } \\
\text { waste our time to get information for that you know. Each group .. together } \\
\text { information you know.. that helped us. }\end{array}$ \\
\hline $\begin{array}{l}\text { Variety of assessment } \\
\text { options }\end{array}$ & 4 & $\begin{array}{l}\text { I like that we do what we like to present our work. } \\
\text { We can present doing many things like creating slides and talking over it. }\end{array}$ \\
\hline
\end{tabular}

Although the UAE context of learning is quite conservative, when asked whether mobile learning apps and Web 2.0 tools should be used in the academic English classes, twenty-two out of thirty female Emirati students reported that they would like it. As expected, all participants owned a MacOS laptop, an iPad and a Smartphone reflecting the uniqueness of the region and the government's support for mobile initiatives in education. Also, students' replies to the second closed-ended question showed that most of them preferred using MALL apps and Web 2.0 tools for learning activities while a third of the students wished to use them "sometimes" and only two students preferred using "no" MALL apps and Web 2.o tools. Participants stated in their responses to question four that following a Keynote airdropped to them by the teacher with all lesson activities in it was helpful to learn and remember the content. Their responses included "...easy for us to remember the vocabulary", "The activities for my group were in it and it was fun", and "After the lesson, I tried to communicate with others using the vocabulary in the Keynote". This was reflected in the common themes in open-ended responses in the paper-based questionnaire such as "learning from each other", "fun" and "collaboration".

The responses to question five showed that the majority of the participants particularly found having differentiated activities useful for their learning. These activities seemed to have helped their learning by enabling multiple entry points to introduce new content and activating student interest through "multi-modal texts". "...help me to brainstorm for new ideas with my group and put some plan before start" and "I could take my time with my group to find out key ideas in reading" are two out of the twenty-one positive student responses. Questions six, seven and nine focused on the MALL apps and Web 2.0 tools used during the differentiated lessons and the themes "providing feedback" and "personalization" were often mentioned by the participants. However, according to one of the participants "...it is sometimes difficult to see what the colors mean and hard to correct mistakes". This shows that although providing feedback is an essential feature of a language learning app, it should not be time-consuming and confusing for the students. While many students may be more skilled with the use of apps and tools, there are still students who struggle with these technologies and ongoing support, scaffolding and choices need to be given to all students.

Data collected from the semi-structured interviews also identified "giving feedback" and "collaboration" as two ways to assist EAP students in their learning in higher education classes. MALL apps and Web 2.0 tools in differentiated classes work positively on many levels such as improving motivation and concentration (Lee, Han \& Lee, 2009) which lead to enjoyment, relaxation, information acquiring and better time management. 
While the participants noted in the collected data that using MALL apps and Web 2.0 tools may be challenging, the majority of participants also believed that the overall experience helped them enhance particular skills such as conversational skills, research and organization skills, and they enjoyed greater convenience in regards to having mobile learning assessment options.

\section{CONCLUSION}

With the points stated, it is important that educators ensure effective use of educational technologies by providing students options and giving them the freedom of choice, while making students feel more comfortable in their abilities. Providing mentoring, training and support to students will enable them to practice $21^{\text {st }}$ century skills including communication, collaboration, and content creation.

Throughout the course of this study, several factors were identified that may have caused limitations to the outcomes of the study. The first limitation is on the number of participants. There are thirty participants in this study which is due to time constraints as the study took place nearing the end of the fifteen-week semester, and this number does not reflect the EAP language teaching practice at the foundation program completely. The presentation of two separate differentiated lessons occurred in weeks nine and eleven during a semester of fifteen weeks, and were completed in two to three days, which was followed by interviews with five participants. This number should be expanded to a higher number for a more accurate result as the participation of a bigger population could be better generalized. Likewise, gender was another limitation that could have impacted the results of the study. Since the research was conducted on a group of female students who were in two separate classes, perhaps including male students in the study would have given varied results. Moreover, students' motivation might have represented a possible limitation and as most of them were already repeating the course, they felt responsible for their learning and results, which may have affected their responses to the open-ended questions in the paper-based questionnaire. Finally, from the researcher's perspective, preparation time for the differentiated lessons which included a variety of activities was an important factor which was burdensome to the researcher who needed to be timely with data collection and analysis.

In regards to the recommendations, the results of this study shed light on several suggestions for further research:

i) There is a necessity to consider differentiating instruction and including MALL apps and Web 2.0 tools in EAP classes in higher education as meeting the learning needs of academically diverse students and raising student achievement are the priority in today's higher education classrooms. The themes from this research revealed that implementing differentiated instruction including MALL apps and Web 2.0 tools can instill a new excitement for learning to all students as it can provide enrichment opportunities to further accelerate students' EAP learning. Thus, there is a need to investigate the utilization of differentiated instruction with MALL apps and Web 2.0 tools in all four skill areas of English language for teaching and learning. Also, more studies on ways to include MALL apps and Web 2.0 tools in collaborative learning are encouraged.

ii) There is a need to create more Personal Learning Environments (PLNs) and professional development opportunities for teachers since they provide teachers with a common goal to collaborate on how to best differentiate instruction and ways to incorporate MALL apps and Web 2.0 tools. Thus, further research in this area would benefit higher education institutions and provide a clear understanding of the concept.

iii) This research study focused on collecting qualitative data through the means of a paper-based questionnaire and semi-structured interviews. It included the presentation of two differentiated lessons that occurred in two separate weeks of a semester. It is highly recommended that further studies be conducted in UAE in other contexts that adopt a mixed-method design in order to collect data on more participants, including their classroom experience and their language learning. Also, there is a definite need for further studies with a population of male learners to investigate their perceptions of differentiated lessons with MALL apps and Web 2.0 tools.

The results of this study indicate that the usage of MALL apps and Web 2.0 tools in differentiated EAP classes in higher education assist students in terms of feedback, motivation, collaboration, pace, multi-modality and research skills, and gives them an opportunity to choose the activity and assessment for themselves that corresponds to their needs and abilities. The task of creating differentiated learning pathways for students that integrate MALL apps and Web 2.0 tools is a challenging aim and as McLoughlin and Lee (2010) suggest it requires "not only the espousal of appropriate teaching approaches, but also awareness of the 
learner experience, and the importance of valuing learners' pre-existing skills" (p.38). Thus, there is a fundamental need for future research to be conducted on EAP students' classroom experience and their language learning in differentiated lessons that integrate MALL applications and Web 2.0 tools in UAE higher education. The research study concludes that the introduction of differentiated instruction using MALL apps and Web 2.0 tools into the educational process contributes not only to a deeper assimilation of knowledge, but also to the formation of motivation and self-esteem of students.

\section{REFERENCES}

Abdulla, F. et al. 2011. Where Are All the Men? Gender, Participation and Higher Education in the United Arab Emirates. Dubai School of Government. Working Paper Series, pp. 3-11.

Armstrong, T. (2009). Multiple Intelligences in the Classroom. Association for Supervision and Curriculum Development, VA.

Biggs, J. B. et al. 2011. Teaching for Quality Learning at University. ( $4^{\text {th }}$ ed.). McGraw-Hill Education, New York.

Gregory, G. H. et al, 2004. Data Driven Differentiation in the Standards-based Classroom. Thousand Oaks, CA.

Henard, F. et al, 2008. The Path to Quality Teaching in Higher Education. OECD-IMHE. Retrieved from: http://www.oecd.org/education/imhe/44150246.pdf

Koutselini, M. 2008. Listening to Students' Voices for Teaching in Mixed Ability Classrooms: Presuppositions and Considerations for Differentiated Instruction. Learning and Teaching, Vol.1, No. 1, pp. 17-30.

Lee, C. H. et al, 2009. Study on the Analysis of Effectiveness of the U-learning Research School. The Society of Korean Practical Arts Education, Vol. 15, No. 2, pp. 312-332.

McLoughlin, C. et al, 2010. Personalized and Self-regulated Learning in the Web 2.0 Era: International Exemplars of Innovative Pedagogy Using Social Software. Australasian Journal of Educational Technology, Vol. 26, No. 1, pp. 28-43.

NMC Horizon Report 2017: Higher Education. (2017). New Media Consortium (NMC). Retrieved from: http://cdn.nmc.org/media/2017-nmc-horizon-report-he-EN.pdf

Prud'homme, L. et al, 2006. Building an Island of Rationality Around the Concept of Educational Differentiation. Journal of the Canadian Association for Curriculum Studies, Vol. 4, No. 1, pp. 129-151.

Rugh, W.A. 2002. Arab Education: Tradition, Growth and Reform. The Middle East Journal, Vol. 56, No. 3, pp. 396-414.

Stradling, B. et al, 1993. Differentiation in Practice: Responding to the Needs of All Pupils. Educational Research, Vol. 35, No. 2, pp. 127-137.

Subban, P. 2006. Differentiated Instruction: A Research Basis. International Education Journal, Vol. 7, No.7, pp. 935-947.

Tomlinson, C.A. 1999. The Differentiated Classroom: Responding to the Needs of All Learners. Association for Supervision and Curriculum Development, Alexandria, VA.

Tulbure, C. 2011. Differentiate Instruction for Pre-service Teachers: An Experimental Investigation. Procedia-Social and Behavioral Sciences, Vol. 30, pp. 448-452.

West, D. 2013. Mobile Learning: Transforming Education, Engaging Students, and Improving Outcomes. Retrieved from: https://www.brookings.edu/wp-content/uploads/2016/06/BrookingsMobileLearning_Final.pdf 